\title{
Peran Organisasi Sayap Partai Politik dalam Kaderisasi Partai Politik di Indonesia
}

\author{
Septi Nur Wijayanti ${ }^{1}$, Kelik Iswandi ${ }^{2 *}$ \\ 1, 2, Fakultas Hukum Universitas Muhammadiyah Yogyakarta, Yogyakarta, Indonesia \\ *E-mail: kelik.iswandi.2016@law.umy.ac.id
}

\begin{tabular}{|c|c|}
\hline Dikirim: 07/06/2021 & Dipublikasi: 31/12/2021 \\
\hline Info Artikel & Abstract \\
\hline $\begin{array}{l}\text { Keywords: } \\
\text { Regeneration; Under } \\
\text { Bow of Political } \\
\text { Party; Political Party. }\end{array}$ & $\begin{array}{l}\text { The political parties that emerge in Indonesia have a distinct catch-all } \\
\text { character; they are dependent on individual figures and lack a defined } \\
\text { socioeconomic foundation. For political parties, the regeneration process } \\
\text { has become a struggle. Because certain political parties lack a clear } \\
\text { regeneration system, oligarchic recruiting is a common occurrence. } \\
\text { Religious affiliations, local links, local commonalities, and proximity to } \\
\text { political party leaders all have a role in recruitment trends. This research } \\
\text { aims to explain the role of the under bow of the political party on } \\
\text { regeneration. This is a legal-normative study that relies on secondary data. } \\
\text { The research material is divided into three categories: primary, secondary, } \\
\text { and tertiary. The following factors, according to this study, influence } \\
\text { political party regeneration and recruitment: 1) political dynasty has an } \\
\text { impact on unhealthy regeneration; 2) political dowry has an impact on } \\
\text { unhealthy competition among political party members; and 3) popularity } \\
\text { factor has an impact on how quickly people can become political party } \\
\text { members. Political parties'inability to recruit and regenerate has an impact } \\
\text { on their capacity to fulfill their role as the primary source of national } \\
\text { leadership selection. Alternative solutions to these problems include } \\
\text { strengthening the under bow of political parties. The existence of under bow } \\
\text { of political parties will aid in the transmission of political party doctrine. } \\
\text { Political parties will be rewarded with the best members who will fight for } \\
\text { their vision and goals. Furthermore, the under bow of political parties can } \\
\text { serve as educational institutions for potential members before they join the } \\
\text { party. }\end{array}$ \\
\hline
\end{tabular}

Kata Kunci:

Kaderisasi;

Organisasi Sayap

Partai Politik; Partai

Politik.

\begin{abstract}
Abstrak
Indonesia mengembangkan partai yang lebih berciri cath-all party, belum memiliki basis sosial yang jelas dan spesifik dan bergantung pada figur individu. Proses kaderisasi menjadi tantangan bagi parpol di Indonesia. Sebagian parpol belum memiliki sistem kaderisasi yang jelas, sehingga sumber rekrutmen politik bersifat oligarkis. Pola rekrutmen berdasarkan faktor primordial seperti agama, hubungan daerah, kesamaan daerah, dan kedekatan dengan pimpinan partai. Tujuan penelitian ini adalah untuk mengetahui sejauh mana peran sayap parpol dalam kaderisasi partai politik. Penelitian ini merupakan penelitian normative yuridis dengan menggunakan data sekunder. Bahan penelitian ini ialah bahan hukum primer, bahan hukum sekunder, dan bahan hukum tersier. Penelitian ini
\end{abstract}


DOI:

menunjukkan bahwa permasalahan kaderisasi dan rekrutmen partai politik muncul akibat; 1) menguatnya politik kekerabatan berdampak tidak sehatnya proses kaderisasi, 2) Mahar politik untuk masuk atau diusung oleh partai berdampak tidak sehatnya kompetisi antar kader partai, 3) adanya faktor popularitas yang menempati posisi kader secara instan. Ketidakmampuan partai dalam rekrutmen dan kaderisasi berdampak partai tidak dapat melakukan fungsinya sebagai pilar utama dalam menyeleksi pemimpin nasional. Penguatan organisasi sayap partai menjadi solusi alternatif atas permasalahan tersebut. Adanya organisasi sayap partai akan mempermudah penanaman ideologi partai. Calon kader sudah memiliki bekal pemahaman ideologi partai. Diperolehnya kader terbaik akan memperjuangkan visi misi partai. Selain itu, organisasi sayap partai dapat menjadi sarana pendidikan bagi kader baru sebelum terjun ke partai.

\section{A. PENDAHULUAN}

Adanya partai politik tidak dapat dilepaskan dari sistem demokrasi. John Aldrich berpendapat bahwa partai politik menjadi poin utama dalam demokrasi. ${ }^{1}$ Dengan demokrasi berarti kekuasaan berada ditangan rakyat, sedangkan rakyat sebagai pemegang kekuasaan tidak dapat menjalankan kekuasaan itu secara langsung, melainkan melalui lembaga perwakilan yang dibentuk dengan pemilu. Sehingga dalam demokrasi perwakilan partai politik menjadi condicio sine qua non bagi bekerjanya mekanisme demokrasi. Dalam konsepsi demokrasi yang ideal, rakyat memiliki peluang besar untuk terlibat dalam proses politik. Proses terbentuknya partai politik merupakan refleksi dari kesadaran masyarakat tentang pentingnya suatu wadah yang mampu memediasi relasi antara pemerintah disatu pihak dan masyarakat dipihak lain. Posisi ini setidaknya mampu menjamin sirkulasi bagi ketersediaan sumber daya kepemimpinan politik pada periode tertentu. Adanya partai politik merupakan keharusan dalam kehidupan politik modern yang demokratis guna mengaktifkan dan memobilisasi rakyat, mewakili kepentingan tertentu, memberikan jalan kompromi bagi pendapat yang berlawanan, serta menyediakan sarana suksesi kepemimpinan politik secara sah dan damai.

Partai politik memiliki beberapa peran diantaranya dalam proses rekrutmen pemimpinpemimpin politik. ${ }^{2}$ Proses rekrutmen dan kaderisasi selama ini cenderung menerapkan pola dan gaya "tradisional". ${ }^{3}$ Proses ini dianggap rahasia sehingga tidak perlu diinformasikan kepada publik. Partai yang dikembangkan lebih berciri catch-all-party (catch-all personalistic dan catch-all programnmatic), belum memiliki basis sosial yang jelas dan spesifik, dan masih tergantung pada figur individu. ${ }^{4}$ Partai partai politik juga menghadapi tantangan dalam proses kaderisasi. Sebagaian partai politik belum memiliki sistem kaderisasi yang jelas, sehingga sumber rekrutmen mempunyai kecenderungan bersifat oligarkis. Pola rekrutmen masih mengikuti garis yang ditentukan oleh faktor-faktor primordial seperti agama, hubungan daerah, kesamaan daerah serta faktor faktor kesetiaan dan kedekatan dengan pimpinan teras partai. Partai Politik juga kurang mendorong keahlian dan kecakapan politik yang memadai agar kader kader partainya siap terjun ke masyarakat dan menjadi solusi atas berbagai persoalan kehidupan berbangsa dan bernegara. Hal itu antara lain sebagai akibat proses politik dan perebutan kekuasaan yang berorientasi jangka pendek, kental oleh kepentingan sesaat. Proses kaderisasi dan rekrutmen juga belum mampu melahirkan kepemimpinan politik yang ideal.

1 Istania, R. (2009). Split Ticket Voting: Menumbuhkan Kegairahan Politik Lokal?. Jurnal Borneo Administrator, $5(1), 1-16$.

2 Sianturi, K. A. (2018). Memperkuat Fungsi Rekrutmen Partai Politik (Strengthening The Recruitment Function of Political Party). Jurnal Legislasi Indonesia, 12(1), 1-22.

Amin, M. (2018). Kaderisasi Partai Politik. Medan: USU Press, 1-128.

4 Aminuddin, M. F., \& Ramadlan, M. F. S. (2015). Match-All Party: Pragmatisme Politik Dan Munculnya Spesies Baru Partai Politik Di Indonesia Pasca Pemilu 2009. Jurnal Politik, 1(1), 39-74.

$$
\text { 476|S A S Vol. } 27 \text { No.4, Oktober - Desember } 2021
$$


Dalam perkembangannya, mekanisme perekrutan yang dilakukan internal partai belum menghasilkan kader yang berkualitas yang diharapkan publik bisa menjadi pemimpin di negara ini, namun kadang perekrutan dan kaderisasi tidak dilakukan secara transparansi. Misal partai politik banyak yang melakukan rekrutmen artis-artis untuk menjadi anggotanya. Tentu rekrutmen artis-artis untuk masuk ke partai politik memberikan harapan bagi partai politik untuk dapat menaikkan elektabilitas partai politik. Elektabilitas partai politik diharapkan dapat naik dengan adanya unsur popularitas artis-artis yang menjadi kader. Rekrutmen ini terkesan tidak mempertimbangkan kemampuan artis untuk terjun di partai politik. Beberapa artis di Indonesia cenderung tidak memiliki dasar politik. Sehingga peran artis setelah terpilih dan duduk di parlemen dirasa kurang memuaskan. Hal ini berakibat pada seringnya dilupakan pentingnya kaderisasi dalam tubuh partai politik.

Pentingnya fungsi rekrutmen politik merupakan fungsi yang memiliki pengaruh kuat pada keberlangsungan partai politik. Sebab dengan mekanisme rekrutmen politik, partai politik dapat menjaring kader-kader baru untuk membangun dan menjalankan partai politik. Selain itu, proses rekrutmen politik juga bertujuan untuk menjaring calon-calon pemimpin yang akan ditawarkan kepada masyarakat. Dalam hal penentuan calon melalui partai politik, Czudnomski menganut dua pola yakni pola terbuka dan pola tertutup. Indonesia cenderung menganut sistem tertutup..$^{5}$

Oleh karena itu, sangat penting dilakukan pengkajian tentang penguatan organisasi sayap partai politik sebagai salah satu alternatif menghasilkan bibit bibit kader yang berkualitas sehingga diharapkan kader yang berkualitas tersebut yang nantinya akan menjadi pemimpin bangsa.

\section{B. METODE PENELITIAN}

Penelitian yang dilakukan termasuk jenis penelitian yuridis normatif adalah metode penelitian hukum yang dilakukan dengan meneliti bahan pustaka atau data sekunder. Penelitiam ini dilakukan untuk mengkaji peran organisasi sayap partai politik dalam kaderisasi partai. Penelitian in menggunakan pendekatan perundang-undangan dan pendekatan konsep. Pendekatan perundang-undangan (statute approach) adalah suatu pendekatan yang dilakukan terhadap berbagai aturan hukum yang berkaitan dengan partai politik dan peraturan organik lain yang berhubungan dengan objek penelitian. Pendekatan konsep (conceptual approach) digunakan untuk memahami teori teori tentang partai politik melalui penelitian yang komprehensif yang mengombinasikan kajian hukum dan politik.

\section{PEMBAHASAN}

\section{Kaderisasi Partai Politik}

Partai politik merupakan salah satu unsur yang harus ada dalam negara demokrasi. Kontribusi partai politik kepada demokrasi ialah melalui fungsinya dalam sistem politik. ${ }^{6}$ Partai politik merupakan alat untuk memperoleh kekuasaan. Menurut Miriam Budiarjo, partai politik ialah sekumpulan orang yang terorganisir yang memiliki kesamaan visi dan misi yang sama untuk memperoleh kekuasaan. ${ }^{7}$ Salah satu fungsi dari partai politik ialah sebagai sarana rekrutmen politik. Setiap partai politik membutuhkan kader-kader terbaik untuk membangun dan mengembangkan partai politik.

Carl J. Friedrich berpendapat bahwa partai politik adalah sekelompok manusia yang

5 Hajad, V. (2016). Kandidasi Partai Aceh Menjelang Pemilihan Gubernur 2017. Government: Jurnal Ilmu Pemerintahan, 9(2), 63-70.

6 Kumar, K. A. (2017). Role and Functions of Political Parties in Democracy. Issue 1 South-Asian Journal of Multidisciplinary Studies (SAJMS), 4(1), 2349-7858.

7 Budiardjo, M. (2008). Dasar-Dasar Ilmu Politik. Jakarta: Gramedia Pustaka Utama.

$$
\text { 477|SASI Vo1. } 27 \text { No.4, Oktober-Desember } 2021
$$


berorganisasi secara stabil dengan tujuan merebut atau mempertahankan penguasaan terhadap pemerintah bagi pimpinan partainya dan berdasarkan penguasaan ini memberikan kepada anggota-anggota partainya kemanfaatan yang bersifat idiil maupun materiil. ${ }^{8}$

Sedangkan Miriam Budiarjo mengartikan bahwa partai politik dapat bertindak sebagai penghubung yang menampung arus informasi, baik informasi yang berasal dari pihak pemerintah/penguasa untuk disalurkan kepada pihak yang diperintah/masyarakat maupun informasi yang berasal dari pihak yang diperintah/masyarakat untuk disalurkan kepada pihak yang memerintah/penguasa. ${ }^{9}$

Senada dengan pendapat diatas Jimly Assiddiqie menyebutkan bahwa dalam hubungannya dengan kegiatan bernegara, peranan partai politik sebagai media dan wahana tentulah sangat menonjol. Di samping faktor-faktor yang lain seperti pers yang bebas dan peranan kelas menengah yang tercerahkan dan sebagainya. Peranan partai politik dapat dikatakan sangat menentukan dalam dinamika kegiatan bernegara. Partai politik sangat berperan dalam dinamis perjuangan nilai dan kepentingan (values and interests) dari konstitusi yang diwakilinya untuk menentukan kebijakan dalam konteks kegiatan bernegara. ${ }^{10}$

Dalam perkembangannya, partai politik di negara-negara berkembang menunjukkan variasi dalam hal tugasnya sebagai organisasi politik. Partai bisa berfungsi sebagai sarana mobilisasi massa, sebagai sarana pemeliharaan kepentingan status quo, atau sebagai media politik berbagai komunitas yang tidak jarang satu sama lain saling bertentangan satu hal jelas bahwa partai di negara berkembang sangat vital sebagai sarana mobilitas massa. Komunikasi politik antara elit politik dan massa sangat dipermudah dengan tampilnya partai sebagai organisasi politik. Elit partai di negara berkembang sangat menikmati fungsi partai karena memungkinkan mereka berkomunikasi dengan lapisan masyarakat paling bawah tanpa kesulitan yang berarti. ${ }^{11}$

Partai politik mempunyai posisi dan peranan yang sangat penting dalam sistem demokrasi. ${ }^{12}$ Partai memerankan peran penghubung yang sangat strategis antara proses-proses pemerintahan dengan warga negara. ${ }^{13}$ Sehingga partai politik merupakan salah satu institusi terpenting dalam praktik demokrasi. ${ }^{14}$ Karena itu partai politik merupakan pilar yang penting untuk diperkuat derajat pelembagaannya dalam sistem politik yang demokaratis. ${ }^{15}$

Partai politik sebagai peserta pemilihan umum mempunyai kesempatan memperjuangkan kepentingan rakyat secara luas, mengisi lembaga-lembaga negara, dan untuk membentuk pemerintahan. Partai politik melalui pelaksanaan fungsi pendidikan politik, sosialiasi politik, perumusan dan penyaluran kepentingan serta komunikasi politik secara riil akan meningkatkan kesadaran dan partisipasi politik masyarakat, merekatkan berbagai kelompok dan golongan dalam masyarakat, mendukung integrasi dan persatua nasional, mewujudkan keadilan,menegakkan hukum, menghormati hak asasi manusia, serta menjamin tercapainya stabilitas keamanan.

Dalam suatu negara demokrasi, partai politik memiliki fungsi penting dalam proses penyelenggaraan kehidupan negara demokrasi. Hasil studi partai politik menunjukkan bahwa

\footnotetext{
Haryanto. (1999). Partai Politik Sebagai Tinjauan Umum. Yogyakarta: Liberty.

Budiardjo, Dasar-Dasar Ilmu Politik.

10 Asshiddiqie, J. (2005). Kemerdekaan Berserikat, Pembubaran Partai Politik Dan Mahkamah Konstitusi. Jakarta: Konstitusi Press.

11 Cipto, B. (1996). Prospek Dan Tantangan Partai Politik. Yogyakarta: Pustaka Pelajar.

12 Asshiddiqie, J. (2006). Parpol dan Pemilu Sebagai Instrumen Demokrasi. Jurnal Konstitusi, 3(4), 6-27.

13 Pinilih, S. A. G. (2017). Mendorong Transparansi Dan Akuntabilitas Pengaturan Keuangan Partai Politik. Mimbar Hukum-Fakultas Hukum Universitas Gadjah Mada, 29(1), 69-81.

14 Yulianti, N. (2015). Phenomena and History of Islamic Political Parties in Indonesia. Analisis: Jurnal Studi Keislaman, 15(2), 385-402.

15 Asshiddiqie, Kemerdekaan Berserikat, Pembubaran Partai Politik Dan Mahkamah Konstitusi.
} 
fungsi partai politik cenderung mengalami transformasi. ${ }^{16}$ Akan tetapi, secara umum fungsi partai politik ialah sebagai sarana komunikasi politik, sebagai sarana sosialisasi politik, sebagai sarana rekrutmen politik, dan sebagai sarana pengatur konflik. Dalam Pasal 11 Undang-Undang Nomor 2 Tahun 2008 tentang Partai Politik menyebutkan bahwa partai politik memiliki lima fungsi yakni sebagai sarana pendidikan politik, sarana pemersatu bangsa atau pengatur konflik, sarana penyalur aspirasi politik, sarana partisipasi politik, dan sarana rekrutmen politik.

a. Partai politik sebagai sarana pendidikan politik

Pendidikan politik (political socialization) merupakan langkah-langkah untuk meningkatkan pengetahuan politik masyarakat dengan tujuan agar masyarakat dapat turut serta berpartisipasi dalam sistem politik. ${ }^{17}$ Beberapa ahli menyatakan bahwa pendidikan politik memiliki makna yang hampir sama dengan sosialisasi politik. Hal ini dikarenakan sosialisasi politik memiliki makna sebagai suatu proses yang menjadi jalan bagi masyarakat untuk menemukan orientasi terhadap fenomena politik. ${ }^{18}$ Akan tetapi, Alfian memberikan uraian makna pendidikan politik yang lebih dalam yakni sebagai upaya untuk mengubah proses sosialisasi politik masyarakat sehingga masyarakat memiliki pemahaman dan menghayati nilainilai yang terkandung dalam sistem politik yang di cita-citakan. ${ }^{19}$ Dewasa ini, tugas pendidikan politik kepada masyarakat hanya dilakukan pada saat kampanye saja atau menjelang pemilihan umum. $^{20}$

Fungsi pendidikan politik di negara demokrasi ialah memberikan kontribusi terhadap proses demokrasi yang berlangsung dan menggalang komunikasi politik yang dapat diterima seluruh kalangan. Sedangkan, tujuan dari adanya pendidikan politik ialah untuk membentuk dan menumbuhkan kepribadian politik dan kesadaran politik demi terciptanya partisipasi politik yang ideal yang membuat rakyat secara bebas dan rahasisa dalam menentukan pilihannya. ${ }^{21}$ Dalam Pasal 31 Undang-Undang Nomor 2 Tahun 2008 tentang Partai Politik menyebutkan bahwa tujuan dari pendidikan partai politik antara lain untuk meningkatkan kesadaran masyarakat mengenai hak dan kewajiban sebagai warga negara, meningkatkan partisipasi politik dan inisiatif masyarakat, dan meningkatkan kemandirian, kedewasaan, dan membangun karakter bangsa dalam rangka memelihara persatuan dan kesatuan bangsa.

Pelaksanaan pendidikan politik oleh partai politik tidak diatur dalam undang-undang dan diberikan kebebasan dengan adanya pembatasan pada keadilan dan kesetaran gender. Dengan demikian, tidak dapat dipungkiri bahwa metode pelaksaan pendidikan politik oleh masingmasing partai politik berbeda. Hal ini disesuaikan dengan kepentingan dan ideologi yang diusung oleh masing-masing partai politik.

b. Partai politik sebagai sarana pemersatu bangsa atau pengatur konflik

Partai politik yang merupakan wadah demokrasi masyarakat menjadi jembatan pemerintah dalam mempersatukan bangsa. Partai politik juga berperan penting dalam mengatur konflik. Akan tetapi, fungsi ini dirasa belum dijalankan maksimal oleh partai politik. Bahkan beberapa kali simpatisan partai politik terlibat konflik dengan simpatisan partai politik lain pada masa kampaye pemilihan umum.

c. Partai politik sebagai sarana penyalur aspirasi politik atau komunikasi politik

16 Pamungkas, S., \& Parlindungan, U. (2011). Partai Politik: Teori dan Praktik di Indonesia. Institute for Democracy and Welfarism.

17 Kantaprawira, R. (1999). Sistem Politik Indonesia: Suatu Model Pengantar. Bandung: Sinar Baru.

18 Budiardjo, Dasar-Dasar Ilmu Politik.

19 Alfian. (1978). Pemikiran dan Perubahan Politik Indonesia: Kumpulan Karangan. Jakarta: Gramedia.

20 Rosana, E. Partai Politik dan Pembangunan Politik. Jurnal Tapis: Jurnal Teropong Aspirasi Politik Islam, 8(1), 135-150.

21 Pasaribu, P. (2017). Peranan Partai Politik Dalam Melaksanakan Pendidikan Politik. JPPUMA: Jurnal Ilmu Pemerintahan dan Sosial Politik UMA (Journal of Governance and Political Social UMA), 5(1), 51-59. 
Fungsi komunikasi politik pada partai politik bertujuan untuk memberikan informasi mengenai program kerja partai politik terhadap anggota partai politik dan ke masyarakat luas. Masyarakat luas dapat menyumbangkan ide gagasan aspirasinya kepada partai politik. ${ }^{22}$ Peran partai politik adalah sebagai wadah penggabungan aspirasi masyarakat. ${ }^{23}$ Aspirasi ini yang kemudian dibawa oleh anggota partai politik yang memiliki kedudukan di lembaga legislatif atau eksekutif dimasukkan menjadi kebijakan pemerintah. ${ }^{24}$ Pelaksanaan fungsi ini berjalan efektif pada saat menjelang pemilihan umum. Partai politik berusaha memberikan programprogram yang menarik konstituen untuk mendulang suara partai politik. Selain itu, komunikasi politik bertujuan untuk memberikan citra yang baik terhadap konstituennya. Oleh karena itu, fungsi partai politik di daerah pemilihan menjadi sangat penting. ${ }^{25}$

Komunikasi politik dapat dilakukan dengan berbagai macam cara, salah satunya media sosial. Media sosial dapat digunakan untuk komunikasi multiarah dan tidak seperti model kampanye tradisional. Kandidat politik dapat memberikan informasi kepada masyarakat dan masyarakat dapat menyampaikan aspirasi kepada kandidat politik. ${ }^{26}$

d. Partai politik sebagai sarana partisipasi politik

Partisipasi politik ialah suatu kegiatan individu atau sekelompok individu untuk ikut aktif dalam kehidupan politik yaitu dengan melalui proses pemilihan pemimpin dan secara langsung maupun tidak langsung mempengaruhi kebijakan pemerintah. ${ }^{27}$ Partisipasi politik menjadi indikator keberhasilan agenda politik yang dilaksanakan oleh pemerintah. Selain itu, partai politik juga menjadi hal yang terpenting dalam pembangunan demokrasi. ${ }^{28}$ Pelaksanaan fungsi partisipasi politik oleh partai politik di Indonesia belum maksimal. Hal ini dikarenakan terdapat beberapa faktor diantaranya faktor kakunya partai politik, kesadaran politik yang masih kurang, rekrutmen politik yang tidak tepat, dan adanya kepentingan sesaat partai politik.

e. Partai politik sebagai sarana rekrutmen politik

Salah satu fungsi dari partai politik ialah rekrutmen politik. ${ }^{29}$ Setiap sistem politik memiliki prosedur yang berbeda dalam proses rekrutmen politik. ${ }^{30}$ Dari keseluruhan fungsi partai politik, fungsi rekrutmen politik merupakan fungsi yang memiliki pengaruh kuat pada keberlangsungan partai politik. Sebab dengan mekanisme rekrutmen politik, partai politik dapat menjaring kader-kader baru untuk membangun dan menjalankan partai politik. Selain itu, proses rekrutmen politik juga bertujuan untuk menjaring dan melatih calon-calon pemimpin yang akan ditawarkan kepada masyarakat. ${ }^{31}$

Berdasarkan pendapat dari Barbara Geddes, sistem rekrutmen dibagi menjadi 4 bentuk,

22 Prianto, B., \& Suharnoko, D. Political Parties and the Recruitment Process of Local Government Heads in Malang Raya. Journal of Public Administration and Governance, 8(4), 187-204.

23 Darmawan, E., \& Septiana, A. (2019). Analisis Fungsi Partai Politik Pada Pilkada Musi Banyuasin 2017 (Studi Terhadap Partai Politik Pengusung Pasangan Dodi Reza dan Beni Hernedi. Jurnal Studi Sosial dan Politik, 3(1), 28-41.

24 Simarmata, M. H. (2018). Hambatan Transparansi Keuangan Partai Politik dan Kampanye Pemilihan Umum. Jurnal Legislasi Indonesia, 15(1), 21-36.

25 Weissenbach, K. (2010). Political Parties and Party Types, Conceptual Approaches to the Institutionalization of Political Parties in Transitional States: The Case of the Philippines. Konrad-Adenauer-Stiftung.

26 Ardha, B. (2014). Social Media Sebagai Media Kampanye Partai Politik 2014 di Indonesia. Jurnal Visi Komunikasi, 13(1), 105-120.

27 Budiardjo, Dasar-Dasar Ilmu Politik.

28 Hussein, H., Riza, M., Pangerang Moenta, A., \& Ilyas, A. (2018). Implementation of Functions of Political Party in Indonesian Constitutional Systems, 80, 146-151.

29 Junaidi, J. (2020). Recruitment/Kaderization Function of Political Party in Local Election with Single Candidate. Melayunesia, 4(1), 56-74.

30 Susanti, S., \& Lubis, A. (2015). Partisipasi Politik Perempuan Pada Partai Keadilan Sejahtera Kota Medan. JPPUMA: Jurnal Ilmu Pemerintahan dan Sosial Politik UMA (Journal of Governance and Political Social $U M A), 3(1), 1-13$.

31 Amundsen, I. (2007). Donor Support to Political Parties: Status and Principles. CMI - Chr. Michelsen Institute. 480|S A S Vol. 27 No.4, Oktober - Desember 2021 
yaitu: ${ }^{32}$

1) Partisanship, model ini memberikan pandangan bahwa proses rekrutmen politik dapat dinilai dengan dasar loyalitas dan pengumpulan partisipan. Model ini kurang memperhatikan kompetensi.

2) Meritocratic, proses rekrumenten dengan memperhatikan kompetensi yang dimiliki seperti teknokrat, pengusaha, guru, pekerja ahli, dan lain-lain. Model ini dapat dikatakan juga suatu model rekrutmen politik yang merekrut kalangan professional.

3) Compartmentalization, proses ini berdasarkan janji meritocratic untuk posisi yang dianggap penting untuk suskes pragmatis dan digunakan untuk dukungan jangka pendek.

4) Survival, sistem ini memiliki dasar pada prinsip timbal balik dan cenderung menjadi patronase.

Proses rekrutmen partai politik dapat dilakukan secara terbuka, semi tertutup, dan tertutup. Terbukanya proses rekrutmen partai politik dipengaruhi oleh keberhasilan implementasi sistem demokrasi dalam suatu negara. Dengan sistem yang terbuka memberikan kesempatan kepada masyarakat untuk memilih pemimpin yang mempunyai kapasitas, integritas, dan akhlak yang baik. $^{33}$

Dalam perkembangannya, masih terdapat permasalahan dalam partai politik, yaitu permasalahan kelembagaan partai politik ${ }^{34}$ dan proses rekrutmen politik oleh partai politik. ${ }^{35}$ Permasalahan kelembagaan partai politik dewasa ini terlihat dengan adanya konflik internal partai politik yang dapat disebabkan oleh perbedaan pilihan koalisi antar kader ${ }^{36}$ dan banyaknya kader partai politik yang terkena kasus korupsi. ${ }^{37}$ Laporan Indonesia Corruption Watch (ICW) pada semester 12020 terdapat 14 anggota partai terkena kasus korupsi. ${ }^{38}$ Hal ini berdampak terhadap menurunnya kepercayaan publik secara masif ${ }^{39}$ karena partai politik cenderung memperjuangkan kepentingan partai dan kelompoknya darupada memperjuangkan aspirasi dan kepentingan rakyat. ${ }^{40}$ Penurunan kepercayaan publik juga dapat disebabkan oleh kegiatan kaderisasi partai politik. ${ }^{41}$ Selain itu, partai politik belum menjadi institusi publik yang memiliki tanggung jawab terhadap pemilihnya. ${ }^{42}$

Permasalahan yang muncul dapat disebabkan oleh tidak transparansinya mekanisme rekrutmen partai politik. ${ }^{43}$ Dalam konteks ini, proses politik yang terjadi di internal partai politik ikut mempengaruhi kualitas dari kandidat pemimpin politik. ${ }^{44}$ Partai politik banyak

32 Junaidi, Recruitment/Regeneration Function of Political Party in Indonesian Local Elections.

33 Gaffar, A. (2006). Politik Indonesia: Transisi Menuju Demokrasi. Yogyakarta: Pustaka Pelajar.

34 Sembiring, M. W., Kusmanto, H., \& Pohan, Z. S. (2018). Recruitment Model of Political Party for a Political Position in North Sumatera Province, Indonesia. Advances in Social Science, Education and Humanities Research, 136.

35 Kambo, G. A. (2017). Institutionalization Process Dymension of Political Parties (Study of Institutionalization of Golkar Party in South Sulawesi Province). 1(2), 77-87.

36 Romli, L. (2018). Koalisi dan Konflik Internal Partai Politik Pada Era Reformasi. Jurnal Politica Dinamika Masalah Politik Dalam Negeri dan Hubungan Internasional, 8(2), 95-118.

37 Imansyah, T. (2012). Regulasi Partai Politik Dalam Mewujudkan Penguatan Peran dan Fungsi Kelembagaan Partai Politik. Jurnal RechtsVinding: Media Pembinaan Hukum Nasional, 1(3), 375-395.

38 Alamsyah, W. (2020). Laporan Pemantauan Tren Penindakan Kasus Korupsi Semester I 2020.

39 Solikhin, A. (2017). Menimbang Pentingnya Desentralisasi Partai Politik di Indonesia. Journal of Governance, 2(1), 36-64.

40 Romli, L. (2016). Reformasi Partai Politik dan Sistem Kepartaian di Indonesia. Jurnal Politica Dinamika Masalah Politik Dalam Negeri dan Hubungan Internasional, 2(2), 199-220.

41 Sahid, A., A., \& Nurjaman, K. (2017). Literasi Politik Masyarakat Pesisir dan Manajemen Partai Politik. JISPO: Jurnal Ilmu Sosial dan Ilmu Politik, 7(2), 137-57.

42 Romli, L. (2016). Masalah Kelembagaan Partai Politik di Indonesia Pasca-Orde Baru. Jurnal Penelitian Politik, 5(1), 21-30.

43 Rachmiatie, A., Hasbiansyah, O., Khotimah, E., \& Ahmadi, D. (2013). Strategi Komunikasi Politik dan Budaya Transparansi Partai Politik. Mimbar: Jurnal Sosial dan Pembangunan, 29(2), 123-132.

44 Hanafi, R. I. (2016). Pemilihan Langsung Kepala Daerah di Indonesia: Beberapa Catatan Kritis Untuk Partai 481|S A S Vo1. 27 No.4, Oktober - Desember 2021 
yang melakukan rekrutmen artis-artis untuk menjadi anggotanya. Tentu rekrutmen artis-artis untuk masuk ke partai politik memberikan harapan bagi partai politik untuk dapat menaikkan elektabilitas partai politik. Elektabilitas partai politik diharapkan dapat naik dengan adanya unsur popularitas artis-artis yang menjadi kader. Hal ini terbukti dengan beberapa artis yang berhadil menjadi anggota Dewan Perwakilan Rakyat.

Tabel 1.

Jumlah Parpol yang Melibatkan Artis di Pemilu Legislatif

\begin{tabular}{cc}
\hline Periode & Jumlah Parpol \\
\hline Pemilu 2004 & 13 dari 48 parpol \\
\hline Pemilu 2009 & 11 dari 38 parpol \\
\hline Pemilu 2014 & 10 dari 12 parpol \\
\hline Pemilu 2019 & 9 dari 16 parpol \\
\hline
\end{tabular}

Diolah dari berbagai sumber.

Pada Pemilu 2019, terdapat 66 artis yang mencalonkan diri menjadi Anggota DPR Periode 2019-2024. Dari 66 artis tersebut, 14 artis lolos menjadi Anggota DPR Periode 20192024. ${ }^{45}$

Tabel 2.

Jumlah Artis dalam Pemilu Legislatif Tahun 2019

\begin{tabular}{ll}
\hline \multicolumn{1}{c}{ Nama Partai } & Jumlah Artis \\
\hline Partai Nasional Demokrat (NasDem) & 24 orang \\
\hline Partai Demokrasi Indonesia Perjuangan (PDIP) & 12 orang \\
\hline Partai Kebangkitan Bangsa (PKB) & 7 orang \\
\hline Partai Amanat Nasional (PAN) & 5 orang \\
\hline Partai Berkarya & 4 orang \\
\hline Partai Demokrat & 4 orang \\
\hline Partai Golongan Karya (Golkar) & 3 orang \\
\hline Partai Persatuan Indonesia (Perindo) & 3 orang \\
\hline Partai Gerakan Indonesia Raya (Gerindra) & 3 orang \\
\hline Partai Solidaritas Indonesia (PSI) & 1 orang \\
\hline Jumlah & 66 orang \\
\hline
\end{tabular}

Diolah dari berbagai sumber.

Penggunaan artis di dunia politik dalam jangka pendek masih bisa diterima, akan tetapi dalam jangka panjang dapat menjadi boomerang bagi eksistensi partai politik. Masyarakat menganggap selama ini partai politik tidak mampu melakukan kaderisasi untuk proses alih

Politik. Jurnal Penelitian Politik, 11(2), 1-16.

45 Pambudi, D. (2019). INFOGRAFIK: Daftar 14 Artis Yang Jadi Anggota DPR 2019-2024. kompas.com. https://www.kompas.com/tren/read/2019/09/23/092449065/infografik-daftar-14-artis-yang-jadi-anggota-dpr2019-2024.

482|SASI Vol. 27 No.4, Oktober - Desember 2021 
regenerasi berdasarkan ideologi partai politik. Hal ini berdampak pada partai politik yang lebih suka memilih model instan dengan merekrut artis terkenal untuk menaikkan eksistensi partai politik dalam setiap pemilu legislatif. ${ }^{46}$ Lebih jauh lagi, hal ini berakibat pada dilupakannya proses penting kaderisasi dalam tubuh partai politik.

Rekrutmen politik dari luar kader memiliki dua resiko. Pertama, ketidaksesuaian paham ideologi antara partai politik dengan orang-orang yang direkrut. Kedua, partai politik terjebak dalam kondisi pragmatisme jangka pendek yang menjadikan partai politik merupakan organisasi untuk memperoleh kekuasaan.

Sistem rekrutmen partai politik di Indonesia bersifat tertutup. Partai politik memiliki cara tersendiri dalam menyeleksi kader-kadernya. Terdapat beberapa partai politik melakukan rekrutmen politik dengan membuka pendaftaran melalui website atau bersifat online. Hal ini telah dilakukan oleh Partai Persatuan Indonesia (Perindo) dan Partai Solidaritas Indonesia (PSI). Tujuan utamanya ialah partai politik ingin mejalankan prinsip transparansi dalam rekrutmen politik sehingga masyarakata dapat mengetahui proses mekanisme rekrutmen politik dan diharapkan akan menaikkkan citra politik partai.

Pengaturan mengenai rekrutmen politik diatur dalam Anggaran Dasar atau Anggaran Rumah Tangga partai politik yang kemudian dijabarkan secara teknis melalui Surat Keputusan DPP Partai. Akan tetapi terdapat metode rekrutmen politik yang lazim digunakan oleh partaipartai politik di Indonesia. Mekanisme tersebut ialah melalui proses: pertama, penjaringan yakni partai politik memperkenalkan diri kepada masyarakat yang ingin direkrut. Kedua, partai politik melakukan penyaringan terhadap calon kader yang mendaftarkan diri. Penyaringan ini dilakukan dengan menerapkan kriteria ideal bagi calon kader yang telah dibuat atau ditentukan oleh partai politik. Setelah mekanisme penyaringan selesai, partai politik melakukan penetapan keangotaan yang disesuaikan dengan aturan yang termuat dalam Anggaran Dasar dan Anggaran Rumah Tangga partai politik. Penetapan kader baru dilakukan melalui rapat pengurus partai politik.

\section{Peran Sayap Partai Politik Di Indonesia}

Dalam Pasal 29 Undang-Undang Nomor 2 Tahun 2008 tentang Partai Politik menjelaskan bahwa proses rekrutmen politik berguna untuk mengrekrut anggota partai politik maupun calon legislatif yang akan diusung oleh partai politik tersebut. Selain itu, ketentuan dalam pasal tersebut juga menegaskan bahwa setiap partai politik diharuskan memiliki mekanisme rekrutmen politik sesuai dengan AD dan ART partai politik. Dalam perkembangannya, partai politik dalam melakukan mekanisme rekrutmen politik menggunakan organisasi sayap partai politik. Sayap partai politik memiliki peran penting bagi partai politik dalam melakukan rekrutmen politik. Melalui sayap partai politik, partai politik dapat menjaring kader-kader yang berkualitas dan menunjang keberlangsungan partai politik.

Berdasarkan Penjelasan Pasal 12 huruf j Undang-Undang Nomor 2 Tahun 2008 tentang Partai Politik menyebutkan bahwa organisasi sayap partai politik ialah organisasi yang dibentuk oleh dan/atau menyatakan diri sebagai sayap partai politik sesuai dengan Anggaran Dasar dan Anggaran Rumah Tangga masing-masing partai politik. Dalam Pasal 12 huruf j undang-undang a quo menyebutkan salah satu hak dari partai politik ialah membentuk dan memiliki organisasi sayap partai politik.

Pembentukan organisasi sayap partai politik ialah sebagai pelaksana kebijakan partai, untuk memenuhi kebutuhan strategis dalam memperkuat basis dukungan partai, dan untuk memperkuat fungsi dan peran partai politik di masyarakat. ${ }^{47}$

46 Mustika, R., \& Arifianto, S. (2018). Komodifikasi "Popularitas Selebritis" untuk Mendulang Suara Pemilu Legislatif 2019. Jurnal Studi Komunikasi dan Media, 22(2), 139-50.

47 Febrianty, Y., \& Ghafur, J. (2020). Peran Organisasi Sayap Partai Politik (OSP) dalam Mencegah Kemerosotan 483|S A S Vo1. 27 No.4, Oktober - Desember 2021 
Dalam optik keilmuan, setidaknya ada 3 peran strategis organisasi sayap partai politik:

1) Organisasi sayap partai politik sangat strategis dalam menghubungkan antara partai politik dengan kelompok pemilih yang dapat berbentuk organisasi perempuan, pemuda maupun mahasiswa, serikat buruh, organisasi keagamaan dan organisasi sosial yang lain;

2) Peran organisasi sayap partai politik dapat membantu peran partai politik dalam mengartikulasikan dan mengaggregasikan aspirasi masyarakat atau dapat juga mempengaruhi kebijakan-kebijakan publik.

Dalam perspektif lain menyebutkan peran organisasi sayap partai politik ialah: ${ }^{48}$

1) menjadi penghubung atau penyambung antara kepentingan partai dengan konstiuen;

2) melaksanakan program kerja partai politik secara umum tidak dapat dijangkau oleh struktut inti dalam partai politik;

3) menjembatani kepentingan konstituen dengan partai politik sehingga memberi kemudahan dalam membangun komunikasi politik.

Organisasai sayap partai politik mempunyai fungsi dan peran yang penting bagi partai politik dalam keberlangsungan partai politik. Kedudukan organisasi sayap partai politik berada langsung dibawah partai politik. ${ }^{49}$ Selain itu, organisasi sayap partai politik juga memiliki peran dalam melaksanakan fungsi-fungsi partai politik. Organisasi sayap partai politik dapat berupa organisasi profesi, organisasi perempuan, organisasi pemuda, dan kelompok-kelompok masyarakat tertentu yang terorganisir.

Organisasi sayap partai politik merupakan organisasi otonom partai politik yang memiliki ruang lingkup fokus pada salah satu bidang. Organisasi sayap partai politik melakukan beberapa kegiatan-kegiatan untuk mengimplementasikan program partai politik. Melalui mekanisme ini partai politik dapat lebih dekat dengan masyarakat. Sehingga, partai politik dapat menjaring kader-kader yang dirasa mumpuni untuk dapat bergabung dalam partai politik.

Di Indonesia organisasi sayap partai politik berjumlah sangat banyak dan memiliki variasi massa, sehingga dijadikan media untuk mendulang suara partai politik. Bahkan, tidak ada data pasti berkaitan jumlah organisasi sayap partai politik di Indonesia. Hal ini dikarenakan partai politik diberikan kewenangan untuk membentuk organisasi sayap partai politik tanpa diberikannya batasan maksimal jumlah organisasi sayap partai politik. Kami coba merangkum nama-nama organisasi sayap partai politik yang ada dalam masing-masing partai politik di Indonesia. Akan tetapi, data berikut masih dapat dikoreksi dikemudian hari jika ditemukan organisasi sayap partai politik yang belum terangkum dalam data dibawah ini. Berikut namanama organisasi sayap partai politik di Indonesia yang kami peroleh dari beberapa sumber.

Tabel 1.

Daftar Partai Politik dan Organisasi Sayap Partai Politik di Indonesia

\begin{tabular}{cllll}
\hline No & \multicolumn{2}{l}{ Nama Partai Politik } & \multicolumn{2}{l}{ Nama Organisasi Sayap Partai Politik } \\
\hline & & & a. & Gerakan Mahasiswa Satu Bangsa \\
1. & Partai Kebangkitan & Bangsa & b. DKN Garda Bangsa \\
& (PKB) & c. Majelis Solawat Nusantara \\
& & d. Garda Buruh Migran Indonesia \\
\hline
\end{tabular}

Keanggotaan Partai Politik di Indonesia. In Prosiding Simposium Hukum Tata Negara "Penataan Pengaturan Organisasi Sayap Partai Politik" (1st ed.). Yogyakarta: FH UII Press.

48 Rido, A. (2020). Formulasi Hubungan Organisasi Sayap Partai Politik Dengan Partai Politik di Indonesia. Mei, 1-17. https://fh.uii.ac.id/wp-content/uploads/2019/06/call-for-paper-pshk-fh-uii-dirjen-ahu-kemenhumhamri-formulasi-hubungan-organisasi-sayap-partai-politik-dengan-partai-politik-di-indonesia-ali-rido.pdf.

49 Chandranegara, I. S., \& Paputungan, M. (2020). Kegiatan Organisasi Sayap Partai Politik yang Bertentangan Dengan UUD 1945 Sebagai Alasan Pembubaran Partai Politik Oleh Mahkamah Konstitusi. Jurnal Penelitian Hukum De Jure, 20(1), 117-136.

$$
\text { 484|SASI Vo1. } 27 \text { No.4, Oktober - Desember } 2021
$$




\begin{tabular}{|c|c|c|}
\hline & & $\begin{array}{ll}\text { e. } & \text { Pergerakan Perempuan PKB } \\
\text { f. } & \text { Gerakan Pemuda Kebangkitan Bangsa }\end{array}$ \\
\hline 2. & $\begin{array}{l}\text { Partai Gerakan Indonesia Raya } \\
\text { (Gerindra) }\end{array}$ & $\begin{array}{l}\text { a. Gerakan Rakyat Dukung Prabowo } \\
\text { b. Tunas Indonesia Raya } \\
\text { c. Perempuan Indonesia Raya } \\
\text { d. Gerakan Kristiani Indonesia Raya } \\
\text { e. Gerakan Muslim Indonesia Raya } \\
\text { f. Sentral Gerakan Buruh Indonesia Raya } \\
\text { g. Persatuan Tionghoa Indonesia Raya } \\
\text { h. Satuan Relawan Indonesia Raya } \\
\text { i. Kesehatan Indonesia Raya } \\
\text { j. Gerakan Masyarakat Sanathana Dharma } \\
\text { k. Busantara } \\
\text { 1. Perempuan Indonesia Raya } \\
\text { m. Barisan Restorasi Nelayan, Usahawan, } \\
\text { Buruh, Seniman, Petani Indonesia Raya } \\
\text { n. Gerakan Rakyat Indonesia Baru } \\
\text { o. Garuda Sakti Nusantara }\end{array}$ \\
\hline 3. & $\begin{array}{l}\text { Partai Demokrasi Indonesia } \\
\text { Perjuangan (PDIP) }\end{array}$ & $\begin{array}{ll}\text { a. } & \text { Baitul Muslimin Indonesia } \\
\text { b. Taruna Merah Putih } \\
\text { c. Banteng Muda Indonesia } \\
\text { d. Relawan Perjuangan Demokrasi } \\
\text { e. Gerakan Tani Nelayan Indonesia } \\
\text { f. Pemuda Demokrat Indonesia } \\
\text { g. } \\
\end{array}$ \\
\hline 4. & $\begin{array}{l}\text { Partai Golongan } \\
\text { (Golkar) }\end{array}$ & $\begin{array}{ll}\text { a. } & \text { Angkatan Muda Partai Golkar } \\
\text { b. Kelompok Perempuan Partai Golkar } \\
\text { c. Satuan Kerja Ulama } \\
\text { d. Majelis Dakwah Indonesia } \\
\text { e. Himpunan Wanita Karya } \\
\text { f. Al-Hidayah } \\
\text { g. Angkatan Muda Pembaharuan Indonesia } \\
\text { h. Kesatuan Organisasi Serbaguna Gotong } \\
\text { Royong } \\
\text { i. Sentral Organisasi Karyawan Swadiri } \\
\text { j. Indonesia } \\
\text { k. Ormas Pertahanan Keamanan } \\
\text { 1. Gerakan Karya Rakyat Indonesia } \\
\text { m. Gerakan Pembangunan }\end{array}$ \\
\hline & $\begin{array}{l}\text { Partai Nasional } \\
\text { (NasDem) }\end{array}$ & $\begin{array}{l}\text { a. Badan Advokasi Hukum NasDem } \\
\text { b. Gerakan Massa Buruh } \\
\text { c. Liga Mahasiswa NasDem } \\
\text { d. Persatuan Petani Nasional Demokrat } \\
\text { e. Garda Pemuda NasDem } \\
\text { f. Liga Budaya Nusantara } \\
\text { g. Garda Wanita NasDem } \\
\text { h. Barisan Reaksi Cepat }\end{array}$ \\
\hline
\end{tabular}

6. Partai Gerakan Perubahan -

Indonesia (Garuda)

7. Partai Berkarya a. Pemuda Peduli Soeharto

485|S A S V Vo 1. 27 No.4, Oktober - Desember 2021 


\begin{tabular}{|c|c|c|}
\hline & & $\begin{array}{ll}\text { b. } & \text { Tim Advokat Peduli Soeharto } \\
\text { c. } & \text { Angkatan Muda Partai Berkarya } \\
\text { d. Laskar Berkarya } \\
\text { e. } & \text { Maritim Berkarya } \\
\end{array}$ \\
\hline 8. & Partai Keadilan Sosial (PKS) & $\begin{array}{l}\text { a. Garda Keadilan } \\
\text { b. Gema Keadilan } \\
\text { c. Serikat Pekerja Keadilan } \\
\text { d. Perhimpunan Petani Nelayan Sejahtera } \\
\text { Indonesia } \\
\text { e. Kesatuan Aksi Pelajar Muslim Indonesia } \\
\text { f. Kesatuan Aksi Mahasiswa Muslim } \\
\text { Indonesia } \\
\text { g. Yayasan Pemuda dan Pelajar Asia Pasifik } \\
\text { h. Gugus Tugas Dakwah Sekolah } \\
\text { i. Central for Indonesian Reform } \\
\text { j. Pusat Advokasi Hukum dan Hak Asasi } \\
\text { Manusia } \\
\text { k. Institute for Economics Studies } \\
\text { 1. Institute of Student and Youth for } \\
\text { Democracy } \\
\text { m. Yayasan Pengembangan Sumber Daya } \\
\text { Pemuda }\end{array}$ \\
\hline & $\begin{array}{l}\text { Partai Persatuan Indonesia } \\
\text { (Perindo) }\end{array}$ & $\begin{array}{ll}\text { a. } & \text { Rescue } \\
\text { b. } & \text { Badan Advokasi Rakyat } \\
\text { c. } & \text { Lembaga Kebudayaan Nusantara } \\
\text { d. } & \text { Barisan Usaha Masyarakat Indonesia } \\
\text { e. } & \text { Pemuda Perindo } \\
\text { f. } & \text { Serikat Buruh Perindo } \\
\text { g. } & \text { Persatuan Pelajar dan Mahasiswa } \\
\text { h. } & \text { Tani/Nelayan } \\
\text { i. } & \text { Kartini Perindo } \\
\text { j. } & \text { Gerakan Kasih Indonesia } \\
\text { k. } & \text { Gerakan Rajawali Perindo } \\
\end{array}$ \\
\hline & $\begin{array}{l}\text { Partai Persatuan Pembangunan } \\
\text { (PPP) }\end{array}$ & $\begin{array}{ll}\text { a. } & \text { Angkatan Muda Kakbah } \\
\text { b. } & \text { Gerakan Pemuda Kakbah } \\
\text { c. } & \text { Generasi Muda Pembangunan Indonesia } \\
\text { d. } & \text { Persaudaraan Muslim Seluruh Indonesia } \\
\text { e. } & \text { Wanita Persatuan Pembangunan } \\
\text { f. } & \text { Gerakan Mahasiswa Islam Indonesia }\end{array}$ \\
\hline 11. & Partai Solidaritas Indonesia & - \\
\hline 12. & Partai Amanat Nasional (PAN) & $\begin{array}{l}\text { a. Perempuan Amanat Nasional } \\
\text { b. Barisan Muda Penegak Amanat Nasional } \\
\text { c. Penegak Amanat Reformasi Rakyat } \\
\text { Indonesia } \\
\text { d. Garda Muda Nasional } \\
\text { e. Pandu Indonesia }\end{array}$ \\
\hline & $\begin{array}{l}\text { Partai Hati Nurani Rakyat } \\
\text { (Hanura) }\end{array}$ & $\begin{array}{ll}\text { a. } & \text { Pemuda Hanura } \\
\text { b. } & \text { Srikandi Hanura } \\
\text { c. } & \text { Perempuan Hanura } \\
\text { d. } & \text { Buruh Hanura } \\
\text { e. } & \text { Satria Hanura } \\
\text { f. } & \text { Lembaga Komitmen Tim Rakyat }\end{array}$ \\
\hline
\end{tabular}




\begin{tabular}{|c|c|c|}
\hline & & $\begin{array}{ll}\text { g. } & \text { Laskar Muda Hanura } \\
\text { h. } & \text { Satuan Mahasiswa Pelajar Hanura }\end{array}$ \\
\hline 14. & Partai Demokrat & $\begin{array}{ll}\text { a. } & \text { Forum Komunikasi Pendiri dan Deklarator } \\
\text { b. } & \text { Bartai Demokrat Massa Demokrat } \\
\text { c. Insan Muda Demokrat Indonesia } \\
\text { d. Kader Muda Demokrat } \\
\text { e. Generasi Muda Demokrat } \\
\text { f. Komite Nasional Pemuda Demokrat } \\
\text { g. Angkatan Muda Demokrat } \\
\text { h. Perempuan Demokrat } \\
\text { i. Gerakan Penegak Pancasila Demokrat } \\
\text { j. Angkatan Muda Demokrat Indonesia } \\
\text { k. Angkatan Muda Indonesia Bersatu } \\
\text { l. Aliansi Masyarakat Pemilih Jakarta } \\
\text { m. Benteng Indonesia Raya } \\
\text { n. Bintang Demokrat } \\
\text { o. Forum Komunitas Kebangsaan Indonesia } \\
\text { p. } \text { Gersatu } \\
\text { q. Relawan Biru Indonesia } \\
\text { r. Ikhwanul Muballigin } \\
\text { s. Gerakan Mahasiswa Merah Putih } \\
\text { t. Gerakan Rakyat Demokrat } \\
\text { u. People Aspiration Center } \\
\text { v. Bakti Karya Perjuangan Demokrat }\end{array}$ \\
\hline & Partai Bulan Bintang (PBB) & $\begin{array}{ll}\text { a. } & \text { Forum Caleg Bulan Bintang } \\
\text { b. } & \text { Muslimat Bulan Bintang } \\
\text { c. } & \text { Brigade Hizbullah } \\
\text { d. } & \text { Pemuda Bulan Bintang } \\
\text { e. } & \text { Bulan Sabit Merah } \\
\text { f. } & \text { Laskar Hijau }\end{array}$ \\
\hline & $\begin{array}{l}\text { Partai Keadilan dan Persatuan } \\
\text { Indonesia (PKPI) }\end{array}$ & $\begin{array}{l}\text { a. Gerakan Muda PKP Indonesia } \\
\text { b. Barisan Perempuan PKPI }\end{array}$ \\
\hline
\end{tabular}

Diolah dari berbagai sumber

\section{Penguatan Peran Organisasi Sayap Partai Politik Dalam Kaderisasi Politik}

Idealnya partai adalah wadah untuk kaderisasi dan ide atau gagasan untuk membangun Indonesia menjadi konteks yang lebih baik. Gagasan ideal bahwa partai sebagai tempat pendidikan, tempat untuk mendidik orang (kaderisasi) dan bukan hanya wadah yang semata mata mencari kekuasaan. Kebutuhuan suatu partai menjadi proses belajar, belajar cara memerintah, belajar cara memimpin, dan belajar cara melayani orang meniscayakan sebuah inovasi bagi semua orang yang mendedikasikan hidupnya di jalur politik untuk mengelola partai dengan cara cara yang baik. ${ }^{50}$

Kaderisasi merupakan hal penting bagi partai politik, karena merupakan inti dari kelanjutan perjuangan partai ke depan dan inti keberadaan partai. Tanpa kaderisasi, sangat sulit dibayangkan partai dapat bergerak dapat melakukan tugasnya dengan baik dan dinamis. Kaderisasi kepemimpinan adalah syarat mutlak dalam membangun struktur kerja yang mandiri dan berkelanjutan.

50 Rido, A. (2020). Formulasi Hubungan Organisasi Sayap Partai Politik Dengan Partai Politik di Indonesia. 487|S A S Vol. 27 No.4, Oktober - Desember 2021 
Kaderisasi berkaitan sekurang kurangnya beberapa hal, antara lain; pertama, bagaimana partai politik menyiapkan kader kader partai politiknya. Dalam kaitan itu, kaderisasi berhubungan dengan kemampuan dan kapasitas politik. Kedua, kaderisasi berhubungan dengan sistem karier atau jenjang politik yang akan dibentuk partai politik. Ketiga, kaderisasi berhubungan dengan bagaimana partai politik melakukan pendidikan politik pada kader kadernya. Keempat, regenerasi berhubungan dengan subyek yaitu individu individu atau sekelompok orang yang dipersiapkan untuk meneruskan visi dan misi organisasi. Kaderisasi merupakan tanggung jawab dan peran dari seluruh standar organisasi partai baik organisasi partai di tingkat nasional sampai bawah (ranting-ranting). ${ }^{51}$

Organisasi sayap partai politik adalah perpanjangan tangan dari partai politik, sehingga secara tidak langsung peran organisasi sayap partai politik sangat besar dalam menjalankan visi dan misi partai. Partai politik harus melaksanakan fungsi partai politik tidak hanya sebatas pada kader dan pengurus partai politik, namun juga harus menembus kader kader organisasi sayap partai politik sehingga diharapkan dengan adanya pendidikan politik dapat menciptakan bibit bibit unggul kader partai politik.

Organisasi sayap partai politik tidak dapat dipisahkan dari partai politik. Organisasi sayap partai politik berperan penting dalam proses rekrutmen dan kaderisasi partai politik. Organisasi sayap partai politik menjadi media untuk menjaring kader-kader partai politik. Mekanisme rekrutmen ini lebih mudah daripada mekanisme rekrutmen dari luar organisasi sayap partai politik. ${ }^{52}$ Selain itu, pemahaman ideologi partai politik dapat diserap secara optimal oleh calon kader dari sayap partai politik. Rekrutmen politik dari sayap partai politik akan menjadi metode untuk perluasan basis partai politik. Sehingga, dapat menaikkan perolehan suara pada pemilihan ini. Sehingga dapat dikatakan bahwa rekrutmen politik melalui organisasi sayap memiliki banyak keuntungan dan kemudahan daripada rekrutmen politik dengan metode penjaringan diluar organisasi sayap partai politik. Dalam mendekati masa pemilu, organisasi sayap partai politik digunakan sebagai alat untuk memperoleh dukungan politik. Organisasi sayap partai politik dapat menjadi media pendidikan dan pelatihan bagi kader-kader baru partai politik. Sehingga, kader-kader partai politik yang lahir dari organisasi sayap partai politik dapat memiliki kapasitas dan kapabilitas untuk terjun ke partai politik. Diharapkan dengan adanya penguatan peran organisasi sayap partai politik dalam kaderisasi akan mencipatakan sistem rekrutmen dan kaderisasi yang baku, transparan, demokratis dan akuntabel, sehingga bisa mencetak sumber daya manusia yang berkualitas untuk menjadi pemimpin di negara kita.

\section{P E N U T U}

Partai politik memiliki peran penting dalam negara demokrasi. Adanya partai politik merupakan suatu keharusan bagi negara. organisasi sayap partai politik sangat berperan penting dalam proses rekrutmen politik. partai politik dapat melakukan internalisasi ideologi kepada calon kader dari sayap partai politik lebih mudah dibandingkan mekanisme rekrutmen politik dari luar organisasi sayap partai politik. melalui organisasi sayap partai politik, partai politik dapat melakukan pendidikan dan pelatihan pada calon-calon kader partai politik. Sehingga, nantinya ketika kader-kader tersebut bergabung dengan partai politik sudah memiliki kemampuan yang mumpuni untuk menjalankan dan mengembangkan partai politik. Dengan demikian, eksistensi dari sebuah partai politik dapat terus berkembang dan berperan penting dalam kemajuan demokrasi di Indonesia.

51 Haris, S., Bhakti, I. N., Nurhasim, M., Nuryanti, S., Yanuarti, S., Tryatmoko, M. W., Gayatri, I. H., Kartini, I., Siregar, S. N., \& Budiatri, A. P. (2016). Panduan Rekrutmen \& Kaderisasi Partai Politik Ideal di Indonesia. Jakarta: KPK-LIPI.

52 Haris et al. 


\section{DAFTAR PUSTAKA}

\section{Jurnal}

[1] Aminuddin, M. F., \& Ramadlan, M. F. S. (2015). Match-All Party: Pragmatisme Politik Dan Munculnya Spesies Baru Partai Politik Di Indonesia Pasca Pemilu 2009. Jurnal Politik, 1(1), 39-74.

[2] Ardha, B. (2014). Social Media Sebagai Media Kampanye Partai Politik 2014 di Indonesia. Jurnal Visi Komunikasi, 13(1), 105-120.

[3] Asshiddiqie, J. (2006). Parpol dan Pemilu Sebagai Instrumen Demokrasi. Jurnal Konstitusi, 3(4), 6-27.

[4] Chandranegara, I. S., \& Paputungan, M. (2020). Kegiatan Organisasi Sayap Partai Politik yang Bertentangan Dengan UUD 1945 Sebagai Alasan Pembubaran Partai Politik Oleh Mahkamah Konstitusi. Jurnal Penelitian Hukum De Jure, 20(1), 117-136.

[5] Darmawan, E., \& Septiana, A. (2019). Analisis Fungsi Partai Politik Pada Pilkada Musi Banyuasin 2017 (Studi Terhadap Partai Politik Pengusung Pasangan Dodi Reza dan Beni Hernedi. Jurnal Studi Sosial dan Politik, 3(1), 28-41.

[6] Hajad, V. (2016). Kandidasi Partai Aceh Menjelang Pemilihan Gubernur 2017. Government: Jurnal Ilmu Pemerintahan, 9(2), 63-70.

[7] Hanafi, R. I. (2016). Pemilihan Langsung Kepala Daerah di Indonesia: Beberapa Catatan Kritis Untuk Partai Politik. Jurnal Penelitian Politik, 11(2), 1-16.

[8] Hussein, H., Riza, M., Pangerang Moenta, A., \& Ilyas, A. (2018). Implementation of Functions of Political Party in Indonesian Constitutional Systems, 80, 146-151.

[9] Imansyah, T. (2012). Regulasi Partai Politik Dalam Mewujudkan Penguatan Peran dan Fungsi Kelembagaan Partai Politik. Jurnal RechtsVinding: Media Pembinaan Hukum Nasional, 1(3), 375-395.

[10] Istania, R. (2009). Split Ticket Voting: Menumbuhkan Kegairahan Politik Lokal?. Jurnal Borneo Administrator, 5(1), 1-16.

[11] Junaidi, J. (2020). Recruitment/Kaderization Function of Political Party in Local Election with Single Candidate. Melayunesia, 4(1), 56-74.

[12] Kambo, G. A. (2017). Institutionalization Process Dymension of Political Parties (Study of Institutionalization of Golkar Party in South Sulawesi Province). 1(2), 77-87.

[13] Kumar, K. A. (2017). Role and Functions of Political Parties in Democracy. Issue 1 SouthAsian Journal of Multidisciplinary Studies (SAJMS), 4(1), 2349-7858.

[14]Mustika, R., \& Arifianto, S. (2018). Komodifikasi "Popularitas Selebritis" untuk Mendulang Suara Pemilu Legislatif 2019. Jurnal Studi Komunikasi dan Media, 22(2), 13950.

[15]Pasaribu, P. (2017). Peranan Partai Politik Dalam Melaksanakan Pendidikan Politik. JPPUMA: Jurnal Ilmu Pemerintahan dan Sosial Politik UMA (Journal of Governance and Political Social UMA), 5(1), 51-59.

[16]Pinilih, S. A. G. (2017). Mendorong Transparansi Dan Akuntabilitas Pengaturan Keuangan Partai Politik. Mimbar Hukum-Fakultas Hukum Universitas Gadjah Mada, 29(1), 69-81.

[17] Prianto, B., \& Suharnoko, D. Political Parties and the Recruitment Process of Local Government Heads in Malang Raya. Journal of Public Administration and Governance, 8(4), 187-204.

[18]Rachmiatie, A., Hasbiansyah, O., Khotimah, E., \& Ahmadi, D. (2013). Strategi Komunikasi Politik dan Budaya Transparansi Partai Politik. Mimbar: Jurnal Sosial dan Pembangunan, 29(2), 123-132.

[19]Romli, L. (2016). Reformasi Partai Politik dan Sistem Kepartaian di Indonesia. Jurnal Politica Dinamika Masalah Politik Dalam Negeri dan Hubungan Internasional, 2(2), 199220. 
[20] Romli, L. (2016). Masalah Kelembagaan Partai Politik di Indonesia Pasca-Orde Baru. Jurnal Penelitian Politik, 5(1), 21-30.

[21]Romli, L. (2018). Koalisi dan Konflik Internal Partai Politik Pada Era Reformasi. Jurnal Politica Dinamika Masalah Politik Dalam Negeri dan Hubungan Internasional, 8(2), 95 118.

[22] Rosana, E. Partai Politik dan Pembangunan Politik. Jurnal Tapis: Jurnal Teropong Aspirasi Politik Islam, 8(1), 135-150.

[23] Sahid, A., A., \& Nurjaman, K. (2017). Literasi Politik Masyarakat Pesisir dan Manajemen Partai Politik. JISPO: Jurnal Ilmu Sosial dan Ilmu Politik, 7(2), 137-57.

[24] Sembiring, M. W., Kusmanto, H., \& Pohan, Z. S. (2018). Recruitment Model of Political Party for a Political Position in North Sumatera Province, Indonesia. Advances in Social Science, Education and Humanities Research, 136.

[25] Sianturi, K. A. (2018). Memperkuat Fungsi Rekrutmen Partai Politik (Strengthening The Recruitment Function of Political Party). Jurnal Legislasi Indonesia, 12(1), 1-22.

[26] Simarmata, M. H. (2018). Hambatan Transparansi Keuangan Partai Politik dan Kampanye Pemilihan Umum. Jurnal Legislasi Indonesia, 15(1), 21-36.

[27] Solikhin, A. (2017). Menimbang Pentingnya Desentralisasi Partai Politik di Indonesia. Journal of Governance, 2(1), 36-64.

[28] Susanti, S., \& Lubis, A. (2015). Partisipasi Politik Perempuan Pada Partai Keadilan Sejahtera Kota Medan. JPPUMA: Jurnal Ilmu Pemerintahan dan Sosial Politik UMA (Journal of Governance and Political Social UMA), 3(1), 1-13.

[29] Yulianti, N. (2015). Phenomena and History of Islamic Political Parties in Indonesia. Analisis: Jurnal Studi Keislaman, 15(2), 385-402.

\section{Buku}

[30] Alfian. (1978). Pemikiran dan Perubahan Politik Indonesia: Kumpulan Karangan. Jakarta: Gramedia.

[31]Amin, M. (2018). Kaderisasi Partai Politik. Medan: USU Press.

[32] Amundsen, I. (2007). Donor Support to Political Parties: Status and Principles. CMI - Chr. Michelsen Institute.

[33] Asshiddiqie, J. (2005). Kemerdekaan Berserikat, Pembubaran Partai Politik Dan Mahkamah Konstitusi. Jakarta: Konstitusi Press.

[34]Budiardjo, M. (2008). Dasar-Dasar Ilmu Politik. Jakarta: Gramedia Pustaka Utama.

[35]Cipto, B. (1996). Prospek Dan Tantangan Partai Politik. Yogyakarta: Pustaka Pelajar.

[36]Febrianty, Y., \& Ghafur, J. (2020). Peran Organisasi Sayap Partai Politik (OSP) dalam Mencegah Kemerosotan Keanggotaan Partai Politik di Indonesia. In Prosiding Simposium Hukum Tata Negara "Penataan Pengaturan Organisasi Sayap Partai Politik" (1st ed.). Yogyakarta: FH UII Press.

[37] Gaffar, A. (2006). Politik Indonesia: Transisi Menuju Demokrasi. Yogyakarta: Pustaka Pelajar.

[38]Haris, S., Bhakti, I. N., Nurhasim, M., Nuryanti, S., Yanuarti, S., Tryatmoko, M. W., Gayatri, I. H., Kartini, I., Siregar, S. N., \& Budiatri, A. P. (2016). Panduan Rekrutmen \& Kaderisasi Partai Politik Ideal di Indonesia. Jakarta: KPK-LIPI.

[39] Haryanto. (1999). Partai Politik Sebagai Tinjauan Umum. Yogyakarta: Liberty.

[40] Kantaprawira, R. (1999). Sistem Politik Indonesia: Suatu Model Pengantar. Bandung: Sinar Baru.

[41] Pamungkas, S., \& Parlindungan, U. (2011). Partai Politik: Teori dan Praktik di Indonesia. Institute for Democracy and Welfarism.

[42] Weissenbach, K. (2010). Political Parties and Party Types, Conceptual Approaches to the Institutionalization of Political Parties in Transitional States: The Case of the Philippines. Konrad-Adenauer-Stiftung. 
[43] Alamsyah, W. (2020). Laporan Pemantauan Tren Penindakan Kasus Korupsi Semester I 2020.

[44] Pambudi, D. (2019). INFOGRAFIK: Daftar 14 Artis Yang Jadi Anggota DPR 2019-2024. kompas.com. https://www.kompas.com/tren/read/2019/09/23/092449065/infografikdaftar-14-artis-yang-jadi-anggota-dpr-2019-2024.

[45]Rido, A. (2020). Formulasi Hubungan Organisasi Sayap Partai Politik Dengan Partai Politik di Indonesia. Mei, 1-17. https://fh.uii.ac.id/wp-content/uploads/2019/06/call-forpaper-pshk-fh-uii-dirjen-ahu-kemenhumham-ri-formulasi-hubungan-organisasi-sayappartai-politik-dengan-partai-politik-di-indonesia-ali-rido.pdf. 